\title{
Performed Product Investigation Result Defect Type Code
}

National Cancer Institute

\section{Source}

National Cancer Institute. Performed Product Investigation Result Defect Type Code. NCl Thesaurus. Code C93956.

A coded value specifying the kind of device-related events that characterize the reported event/problem. 